Zbigniew Marek*

ORCID: 0000-0002-4580-1819

Anna Walulik**

ORCID: 0000-0002-5607-6974

Krakow, Poland

\title{
Subjectivity in (of) Education. The Perspective of the Gospel
}

\section{Podmiotowość (w) edukacji. Perspektywa ewangeliczna}

Summary: In the article, we concentrate on the role of the form teacher and pupil in the processes of the humanity formation. We deduce this from the main source of Christian knowledge, which is the Gospel. From this perspective, we indicate the activity of one more upbringing subject who is God seen as a person. In the processes of upbringing inspired by the Gospel, we have to deal with the triad, which comprise of the pupil, form teacher - man and form teacher - God. We seek the answer to the question about understanding the relationship between subjectivity

* Prof. PhD hab. Zbigniew Marek SJ, Department of Andragogy and Pedagogical Axiology in the Institute of Educational Sciences, Faculty of Pedagogy in Jesuit University Ignatianum in Cracow. Address: Akademia Ignatianum w Krakowie, Instytut Nauk o Wychowaniu, ul. Kopernika 26, 31-501 Kraków, Poland; email: zbigniew.marek@ignatianum.edu.pl.

** Phd hab. Anna Walulik, prof. of Jesuit University Ignatianum in Cracow, Head of Department of Andragogy and Pedagogical Axiology in the Institute of Educational Sciences in the Faculty of Pedagogy in Jesuit University Ignatianum in Cracow. Address: Akademia Ignatianum w Krakowie, Instytut Nauk o Wychowaniu, ul. Kopernika 26, 31-501 Kraków, Poland; email: anna.walulik@ignatianum.edu.pl. 
of upbringing and education, which source means the Gospel. It opens new possibilities of development and the feeling of sense of own dignity of both the form teacher and pupil. The crucial role in this process one can designate to the religious education, which aim is to support the man in developing his humanity and achieving its completeness. In these processes, it can appear important to respect the assumption of the pedagogy of accompaniment and witness. These assumptions not only refer to the distinctive tasks of each of the subjects, but they also sensitise the cooperative basis of activity undertaken by each of them.

Keywords: subjectivity; person; God; religious education; analysis of interactions.

Streszczenie: W artykule podejmujemy refleksję nad miejscem oraz rolą wychowawcy i wychowanka w procesach kształtowania człowieczeństwa. Wyprowadzamy ją z głównego źródła wiedzy chrześcijańskiej, jakim jest Ewangelia. Z tej perspektywy wskazujemy na działanie jeszcze jednego podmiotu wychowania, jakim jest osobowy Bóg. W procesach wychowania inspirowanych Ewangelią mamy zatem do czynienia ze swego rodzaju triadą, którą tworzą: wychowanek, wychowawca-człowiek i wychowawca-Bóg. Poszukujemy odpowiedzi na pytanie o rozumienie związków zachodzących pomiędzy podmiotowością wychowania i edukacją, której źródłem jest Ewangelia. Otwiera ona nowe możliwości rozwoju i poczucia własnej godności zarówno wychowawcy, jak i wychowanka. Istotną rolę w tym procesie można przyznać edukacji religijnej, której celem jest wspomaganie człowieka w rozwijaniu jego człowieczeństwa i osiąganiu jego pełni. W procesach tych ważne może okazać się respektowanie założeń pedagogiki towarzyszenia i świadectwa. Założenia te odnoszą się do odmiennych zadań każdego z podmiotów, ale też uwrażliwiają na wspólne podstawy działania każdego z nich. Oznacza to, że edukacja religijna ma charakter kształcenia humanistycznego i religijnego.

Słowa kluczowe: podmiotowość; osoba; Bóg; edukacja religijna; analiza interakcji.

The object of the discussion on upbringing can be one of the queries concerning the role of the form teacher and pupil in the processes of the human formation. In the context of this discussion, significant attention is paid to the subjectivity in upbringing. From the Christian perspective, the upbringing is seen as a process leading the formation of a man who is upstanding, moral, 
who is a good doer, who lives according to the ideas and examples shown to him, who respects God as a person and His law. Such understanding of the process of upbringing is based on the Christian personalism which describes the human nature as a "derivative existence"; this means that the man owes his whole existence to God seen as an infinite Existence and stays in the significant dependence of Him. Furthermore, the personalism bears the conviction of necessity to discover the truth about the human person in order to live as a human. This means acting appropriately and performing the human (personal and social) task ${ }^{1}$. Coming to such outlined goals, which are set in front of upbringing, is seen in accompanying ${ }^{2}$ the pupil on the way of constructing the world of values that he/she discovers in the Gospel. It indicates the activity of one more upbringing subject - God, seen also in the personal dimension. He is the definite reference point for the faithful man. Thus, in the processes of upbringing inspired by the Gospel, we address the triad that comprises the pupil, the form teacher - human, and form teacher - God. This need of reflection is justified by feeling that the issue of God appears in the domain of contemporary scientific and social debate on more or less a conscious level ${ }^{3}$.

In this reflection, we seek the answer to the query about understanding the relationship between subjectivity of upbringing and education. The source of this is the Gospel. Thus, our aim is to show that in the processes of upbringing, apart from the form teacher and pupil, one should pay attention to the non-created person - God. Besides, we emphasise that God respects the human freedom ${ }^{4}$, what causes the person to be capable of thinking freely and taking concrete life decisions. It means that the man - as a created existence - has the opportunity to actualise their own potential through developing invention and creativity. These abilities open for him the possibilities coming from outside him, beyond his own limitations, and direct him towards the transcendence; this makes him the eyewitness of himself5.

${ }^{1}$ Zbigniew Marek, Anna Walulik, Pedagogika świadectwa. Perspektywa antropologiczno-kerygmatyczna (Kraków: Akademia Ignatianum, 2019), 22.

${ }^{2}$ Zbigniew Marek, Pedagogika towarzyszenia. Perspektywa tradycji ignacjańskiej (Kraków: Akademia Ignatianum, 2017).

${ }_{3}$ Margaret Scotford Archer, Andrew Collier, Douglas V. Porpora, Transcendence: Critical Realism and God (London and New York: Routledge, 2004), 1.

${ }^{4}$ Krzysztof Stola, "Podmiot", in: Encyklopedia katolicka, vol. XV, ed. Edward Gigilewicz (Lublin: TN KUL Jana Pawła II, 2011), 946-947.

${ }^{5}$ Lucyna Dziaczkowska, "Podmiotowość", in: Encyklopedia aksjologii pedagogicznej, ed. Krystyna Chałas, Adam Maj (Radom: POLWEN, 2016), 783-784. 


\section{Spaces of discovering and forming subjectivity in pedagogy}

The question on understanding subjectivity in the reference to the process of education means the going beyond the Enlightenment defining this category. It demands using different sources, which can help discover its meaning for the pedagogical theory and practice ${ }^{6}$. One of them is the Bible that describes the man's relationship with God and indicates the natural and extra natural possibilities of forming the human subjectivity. We try to discover these possibilities while applying the principles of analysis of interactions on the basis of the story written in the Gospel by Saint John. The story contents comprise Jesus talking with a powerful Jewish teacher called Nikodemus (J 3:1-21):

${ }^{1}$ There was one of the Pharisees called Nicodemus, a leader of the Jews, ${ }^{2}$ who came to Jesus by night and said, 'Rabbi, we know that you have come from God as a teacher; for no one could perform the signs that you do unless God were with him'. ${ }^{3}$ Jesus answered 'In all truth, I tell you, no one can see the kingdom of God without being born from above'. ${ }^{4}$ Nicodemus said, 'How can anyone who is already old be born? Is it possible to go back into the womb again and be born?' 'Jesus replied 'In all truth I tell you, no one can enter the kingdom of God without being born through water and the Spirit; ${ }^{6}$ what is born of human nature is human; what is born of the Spirit is spirit. ${ }^{7}$ Do not be surprised when I say: You must be born from above. ${ }^{8}$ The wind blows where it pleases; you can hear its sound, but you cannot tell where it comes from or where it is going. So it is with everyone who is born of the Spirit'. ' 'How is that possible?' asked Nicodemus. ${ }^{10}$ Jesus replied, 'You are the Teacher of Israel, and you do not know these things! ${ }^{11}$ In all truth I tell you, we speak only about what we know and witness only to what we have seen and yet you people reject our evidence. ${ }^{12}$ If you do not believe me when I speak to you about earthly things, how will you believe me when I speak to you about heavenly things? ${ }^{13}$ No one has gone up to heaven except the one who came down from heaven, the Son of man; ${ }^{14}$ as Moses lifted up the snake in the desert, so must the Son of man be

${ }^{6}$ Leszek Waga, "Integration of Pedagogical Knowledge in the Light of Questions about the Empirical Foundations of General Pedagogy and Understanding of the Concept of Generality", Peadagogia Christiana 2/42 (2018): 67-68. 
lifted up ${ }^{15}$ so that everyone who believes may have eternal life in him. ${ }^{16}$ For this is how God loved the world: he gave his only Son, so that everyone who believes in him may not perish but may have eternal life. ${ }^{17}$ For God sent his Son into the world not to judge the world, but so that through him the world might be saved. ${ }^{18}$ No one who believes in him will be judged; but whoever does not believe is judged already, because that person does not believe in the Name of God's only Son. ${ }^{19}$ And the judgement is this: though the light has come into the world people have preferred darkness to the light because their deeds were evil. ${ }^{20}$ And indeed, everybody who does wrong hates the light and avoids it, to prevent his actions from being shown up; ${ }^{21}$ but whoever does the truth comes out into the light, so that what he is doing may plainly appear as done in God.'

In this story, we noted some actors of the first and background plan, but more precisely speaking, those who build the narration "here and now" (Nikodemus, Jesus, Father, Spirit) and those who participate in the fruits of the discussion conveyed within it, or reject them. Thanks to those persons, the reality discovered by Jesus is timeless (the Man; everyone who was born through the Spirit; you; everyone who believes in Him; everyone who does not believe in Him; everyone who perpetrates the wickedness). The graphic relations between the indicated actors are shown in graph 1 .

Nikodemus is the Jewish nobleman, the Israeli teacher ( $\mathrm{J} 3: 1 ; 10)$. He is the representative of Jerusalem citizens, who heard about the signs made by Jesus. He acknowledges in Jesus the teacher coming from God, and in His signs sees the witness of authenticity of His mission. Jesus is One, who makes signs, as God is with him. He is regarded as a Rabbi, who came from God as a teacher. He has the conscience that is the Only-begotten Son of Father, who descended from Heaven, so He is also the Son of Man. He came on earth in order to save the world, that is why he calls Himself a Light (J 21:13; 16-17;19). The real presence of the Father and Holy Spirit in the conveying dialogue is represented by Jesus, for $\mathrm{He}$ is not only the human, but He is God as well. Father is the God, who sends his Son on earth from love to the man (J 3:16-17), and Spirit is the one who gives a new birth to the human (J 3:8). He is put in opposition to the human body; this reflects the fundamental difference between God and His creation: "what is born of human nature is human; what is born of the Spirit is spirit" (J 3:6). From the perspective of analysis of interactions one can see Father, Son, and Spirit as a collective actor, because their acts of doing and their results cannot be put apart, which in fact is in the accordance to the Catholic truth of faith about The Most Holy Trinity. 
[16]

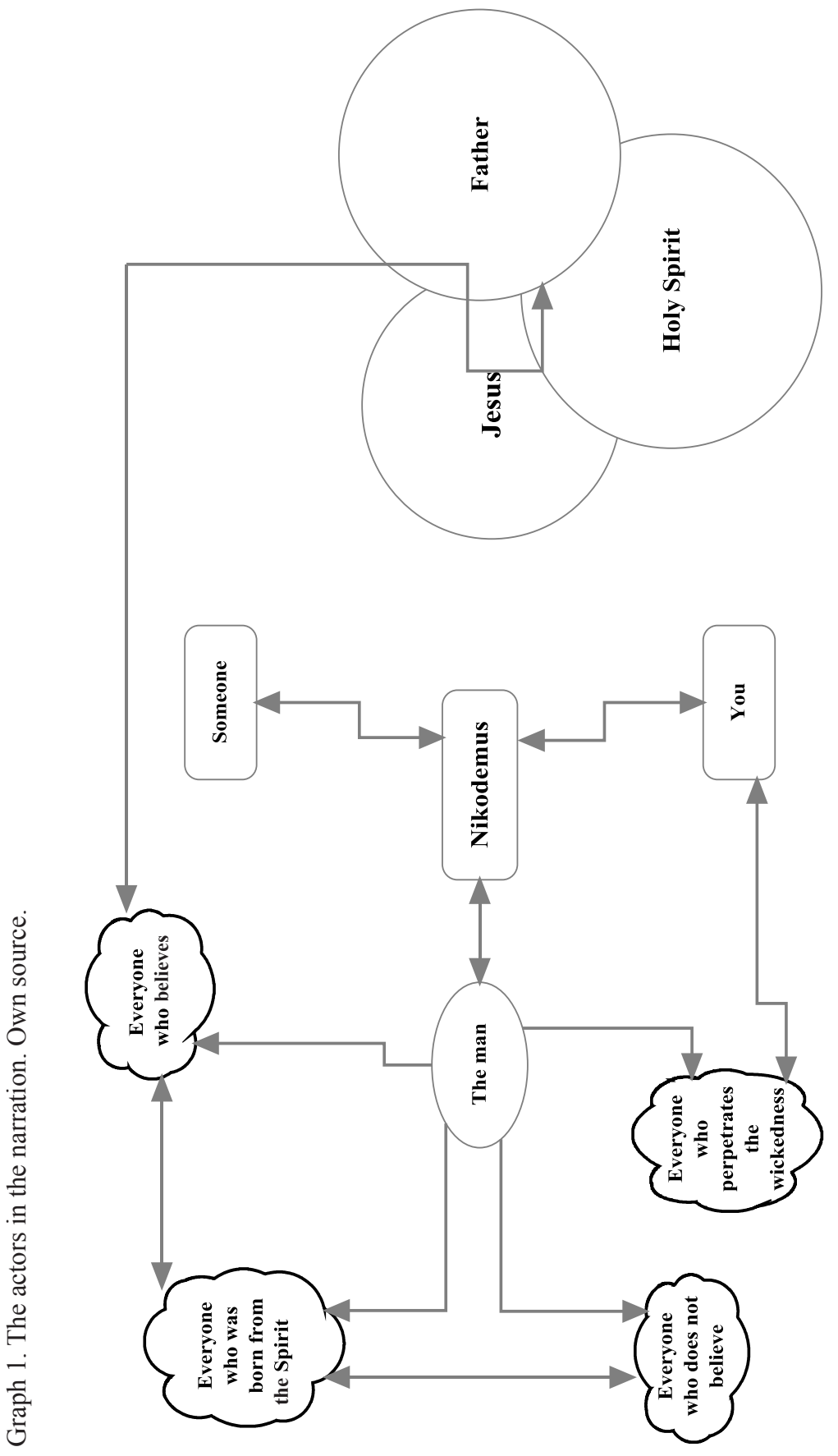


The reality that is explained by the actors of the first plan creates the space of activity of actors from the background. The narrator does not call them by name. One can describe them in dependence on the fact, if they use or reject the results of the acts of doing performed by the actors from the first plan. They are: man, everyone who was born from the Spirit; everyone who believes in Him; everyone who realises the demands of truth; everyone, who does not believe; everyone who goes towards wickedness; you. In this case, one can also include that the actors whose acts of doing are individual (they are signed as the pronoun who or everyone) and those whose acts are in common with the group (man, you). The actor who connects all the activities of the actors belonging to this group is the man, who can accept or reject God's offer and decide whether or not to use its results.

The talk between the actors of the analysed event is focused on the question about how a new rebirth can occur. The dialogue appearing from a search of the answer to it does not point at the values acknowledged by the actors from the first plan (see the graph 2).

For Jesus, the prior value is the unity in thinking and acting with the Father and Spirit: "In all truth I tell you, we speak only about what we know and witness only to what we have seen and yet you people reject our evidence. (v. 11); If you do not believe me when I speak to you about earthly things, how will you believe me when I speak to you about heavenly things?" (v. 12).

For Father and Spirit, the value is the glorification of the Son of Man (v. 14-15) and the eternal life, which is the consequence of sending to earth and glorifying the Son of Man (v. 16, 14). The mutual value for Father, Son, and Spirit are: love (in. 16), truth (v. 11), and good (v. 21). Love is expressed in providing all people with the eternal life; the truth allows experiencing in Jesus Christ the true God, and good is the external sign of this experience. All of these values are connected with an expectation of the sign of the taking in of God's kingdom those by whom it is proclaimed and the attainment of the salvation after judgement, "And the judgement is this: though the light has come into the world people have preferred darkness to the light because their deeds were evil" (v. 19).

Standing by good requires the knowledge. This is why both Nikodemus as the representative of what is natural in human, and Jesus, embodying what is supernatural, acknowledge the knowledge as a value. In this way, they indicate the necessity of adequate deployment of cognition based on the intellect and faith. 
[18]

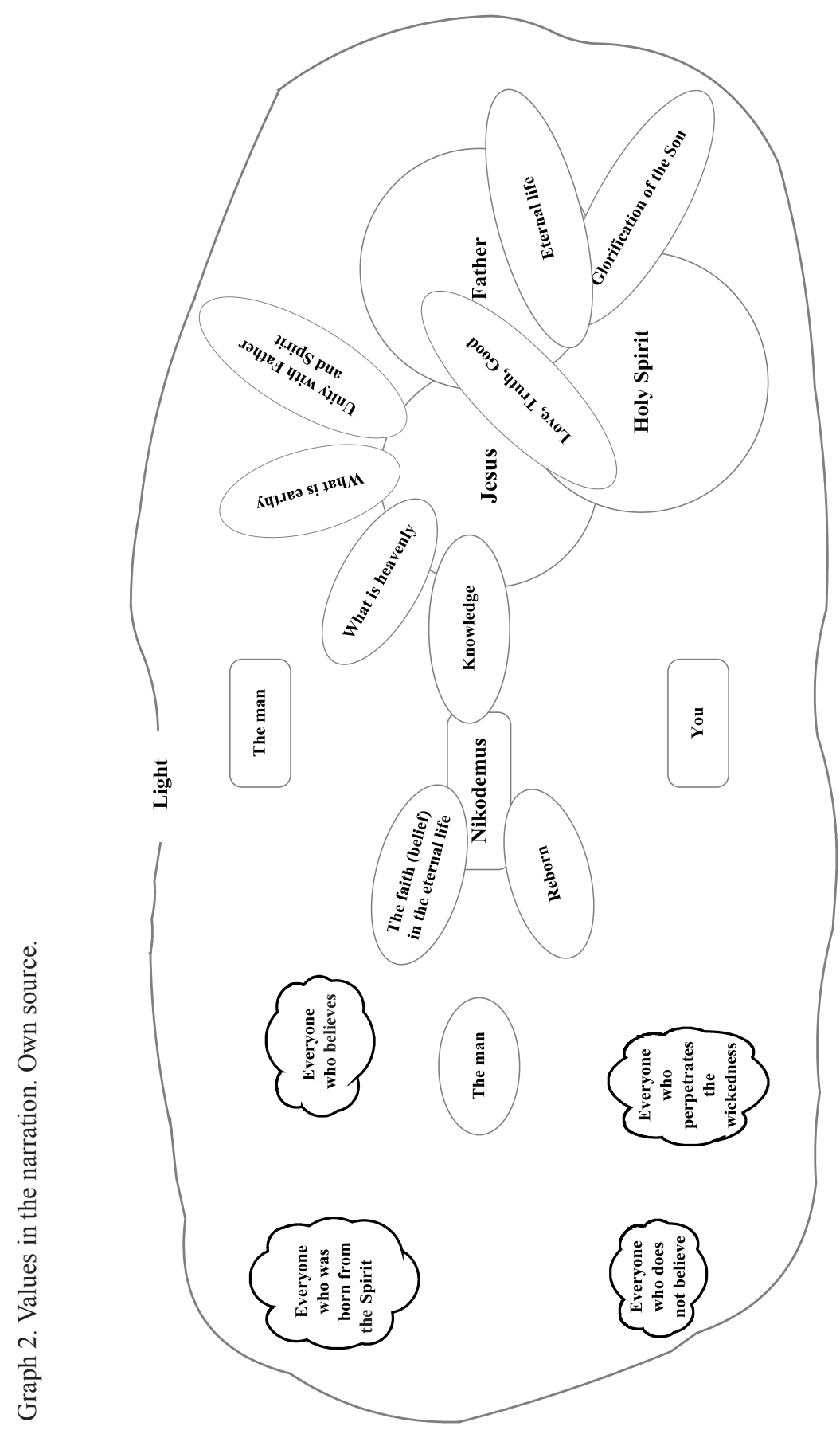


The Light already mentioned is also the value and expectation for all the actors. The Light is the metaphor ${ }^{7}$, which opens the extraordinary perspective of understanding the reality of new rebirth (v. 3.7). The metaphor of Light refers to Jesus - is his name, which in the biblical understanding means the identity of person. Hence, Jesus speaks about the witness, which He gives through his life on the earth - both with words and acts of doing (signs), which Nikodemus acknowledges as values (v. 2).

Other values for Nikodemus are rebirth and belief in the eternal life (v. 3-4), which Jesus treats as the condition to enter God's kingdom. To make Nikodemus easier understand this reality, Jesus uses another metaphor: "birth from water and Spirit". You should notice that we have to address this specific sort of meta-metaphor. With it, Jesus explicates that the God's kingdom demands "new birth", which comprises in itself both things: corporal and spiritual. "New birth" requires the transformation of a person in his/her natural and beyond natural dimension (v. 11-12). This process runs in time, which appears to be the next category indicated in the conducted analysis. Within this category, there were four entities mentioned ${ }^{8}$ : night (v. 1), once more (v. 4), repeatedly (in. 4), then (v. 4).

The first of them (night) refers to Nikodemus and Jesus, so to actors of the first plan. It informs about the meaning which Nikodemus gives to the meeting already described. On the one hand, choosing the night as the time of the meeting with Jesus, he makes an attempt to obtain the opinion of members of his association, which is against Jesus and that is why he tries to be not seen. On the other hand, he is against the principles accepted by them. These principles say that leaving the home at night and wandering solitary in the streets are something unacceptable, according to Talmud. The night is the time the philosopher (scientist) should use for studying the Law and prayer. Both the first and second explanation of the choice of this time for meeting with Jesus proves that Nikodemus using the natural and extra-natural cognition discovers in Jesus - the Messiah. His desire to confront his own knowledge and belief with the teaching of Jesus, made in such circumstances, show

${ }^{7}$ Anna Walulik, Moderacyjne i synergiczne ksztattowanie dorostości. Propozycja typologii znaczeń wiedzy religijnej (Kraków: WSFP Ignatianum, WAM, 2011), 134-137.

${ }^{8}$ This term comes, can be translated as a one unit, essence, or subject, but in Petera Pin-Shan Chen's understanding it refers both to the real and imaginary thing, which can be clearly identified, differentiated, and connected with relations with others. Such understanding perfectly articulates the sense of the elements indicated in the particular categories. We write more comprehensively about it in: Marek, Walulik, Pedagogika świadectwa, 27. 
the need to surpass the knowledge gained so far and expectations aligned with it. Furthermore, night in the biblical meaning has to be considered also as the metaphor. Night symbolises the temporal world awaiting the salvation, the world, which often is cruel and brings a lot of suffering- the symbol of human sin, in contrary to the symbols of light and day that refer to the redemptive God's intervention. Additionally, the following of day and night one by one, finds deep symbols in the Bible. The day is the sign of lightness of the new world, which is going to be in eternity. Such understanding of this entity demystifies the last three (once more, repeatedly, then), which refers to the actors in the background. They all point at the future-proofed results of a new life, which achieving demands from the man to stand by the Light.

The analysis of the story contents depicted above show the aspects of reflection upon the category of subjectivity in the religious education that refer to actors, values, expectations, and time. Their interpretation conveys a person as a subject of the religious education, designates its range considering the natural and beyond-natural character, which motivates to define the pedagogical implications.

\section{Person as a subject of the religious education}

The story about the meeting between Nikodemus and Jesus told by Saint John has the feature of the religious education comprising the processes of teaching and learning. We mean here, "all the influences" that are needed to obtain competences of everyday interpretation supported by the religious contents 9 . These acts fit into the idea of life-long learning and occur in the social-cultural and creed space. Somehow, they become the social and individual practice, in which the relationship between education, religion, widely understood competences, and the life wisdom occur, building the space in which the relationships between the subjects of upbringing are set in. Thanks to this, the religious education can be realised in different ways; this means that it can take the formal, beyond - formal, and informal shape ${ }^{10}$. The religious education in the analysed Biblical pericope has the informal character. It occurs in the spontaneous (although the idea of it was initiated earlier) relationship: master-pupil.

\footnotetext{
9 Walulik, Moderacyjne, 358-359.
}

10 Janusz Krysztofik, Anna Walulik, "Edukacja religijna i jej miejsce w ponowoczesności”, Studia Katechetyczne. Wspótczesne ujęcia edukacji religijnej 12 (2016): 47. 
The role of the form teacher in this educational situation author appoints to Jesus, who is regarded by Nikodemus as brought up - as the master a person who is extraordinary, and remarkable, who has come from God as a teacher. He calls Him "Rabbi" (v. 2) emphasising "no one could perform the signs that you do unless God were with him" (v. 2). This belief led Nikodemus to the meeting that can be named the religious education.

The righteousness and genuineness of Nikodemus' thinking is confirmed by Jesus who shows the necessity of rebirth that conditions the entrance to the God's kingdom (v. 3), and the foundation for understanding the "heavenly" (v. 11-13) matters (reality). Furthermore, Jesus confirms his own authority and the knowledge of "heavenly matters" to Nikodemus indicating his own dignity: "No one has gone up to heaven except the one who came down from heaven, the Son of man" (v. 13) and naming himself The Only-born Son (v. 16, 18), or the Son of God (v. 17) and the light that came to the world (v. 19). From the text analysis comes that Jesus acts as God and human in one person, and in the educational process conducted by himself, He refers to the arguments emerging from both the natural and beyond-natural cognition of faith, called also the religious cognition ${ }^{11}$. The quality of this cognition is the elucidation of reality, which, as a reason driving to the natural assumptions, is not possible to explain. This means that the object of the religious education covers the queries concerning the human existence, his destination, and the sense of life. Although, owing to the natural - empirical cognition, the man is not capable to give the complete answer to these questions, thanks to the religious cognition his knowledge becomes broadened and he gains new arguments widening his horizon of perception of the world. The elements of two ways of the cognition of reality are present also in the activity of Nikodemus, who performs a role of a pupil in this meeting. Even though he is respected and regarded as a teacher by others (v. 1, 3, 5-8, 10), he decides to go to Jesus (v. 2). He is featured with the personal will to know something more than what he can learn from others or listen to from a distance.

The relationship that is conceived in the process of the aforementioned religious education points at an appreciation of dignity of a man who was invited to talk with God since he was born as he exists only because of the fact of being created by God from love and is always kept in love. He does not live in a complete compatibility with truth if he does not definitely accept this love, and if he does not give in to the Creator ${ }^{12}$. Furthermore, the form

11 Zbigniew Marek, Religia pomoc czy zagrożenie dla edukacji (Kraków: WAM, 2014), 50.

12 Catechism of the Catholic Church (Bloomsbury Publishing PLC, 2002), n. 27. 
of its conduction allows us to state that the man in Jesus' eyes is the prior value. In this meaning, one can find the axiological understanding of the term "person", in which one can assume that he/she is the vehicle of values and the subject of rights and duties ${ }^{13}$.

In analysis of the aforementioned relationships between the actors of the first plan and background, one can notice the teacher, who treats the pupil as a subject, not the object of upbringing. Jesus - the teacher - builds his authority not with the professional knowledge, but first of all through the witness ${ }^{14}$. One can say that the question posed by the pupil opens the path of mutual search for truth through the upbringing accompaniment ${ }^{15}$.

Based on the above analysis of the relationship between the actors and values one can draw a conclusion on the rank which the man has for God; as the subject he is the object of His unconditional love. In this way, Jesus discloses to Nikodemus the truth about the man who is for God ever lasting value, for saving for which Jesus has become the Man. The remarkable suggestions concern the fact of how the man can be convinced of being someone precious for God. In discovering this truth, Jesus suggested such thinking to Nikodemus: "No one who believes in him will be judged; but whoever does not believe is judged already, because that person does not believe in the Name of God's only Son" (v. 18-19). Moreover, the truth of these words seals His own divine authority. "In all truth I tell you, we speak only about what we know and witness only to what we have seen and yet you people reject our evidence. If you do not believe me when I speak to you about earthly things, how will you believe me when I speak to you about heavenly things?" (v. 11-12). This means that the subjectivity in the religious education is reflected in the fact that the teacher, aware of his knowledge and the richness of experience, shows the pupil conditions which makes suve that his pursuits and goals will be achieved. Clearly accented conditions of effectiveness of upbringing in the story are: mutual appreciation of dignity of the form-teacher and pupil, and defining the goals outreached the human natural needs. It demands cooperation in pursuing the desired aim. One of the significant motifs of undertaking this sort of activity can be religion.

13 Bartosz Brożek, "O pojęciu osoby”, in: Polonia restituta. Dekalog dla Polski w 100-lecie odzyskania niepodległości, eds. Wit Pasierbek, Anna Teresa Budzanowskia (Kraków: MNiSW, Akademia Ignatianum, 2019), 166.

${ }_{14}$ Marek, Walulik, Pedagogika świadectwa, 296-298.

15 Marek, Pedagogika towarzyszenia, 287-295. 
The specificity of Christian understanding the subjectivity in the processes of the religious education is expressed in the appreciation of the third subject, which is God. In this way, two created subjects (pupil and teacher) participate in the processes of upbringing through the relationships made by them. These subjects get the next relationship with an absolute subject God. Consciousness of this reality seems to be a key to the answer given to the question about how the subjectivity of the man is defined in the pedagogy of religion.

\section{The scope of the interests of the religious education}

The feature of the religious education is promoting the long-lasting, eternal values. In the analysed text, all of these values are described by the term: "God's kingdom" (v. 3) ${ }^{16}$. Jesus explains that the man received the invitation to live in God's kingdom as a result of the love which God gives him (v. 16-17), and his authenticity is confirmed by the Son of Man's death and resurrection (v. 14). The reality of God's kingdom is the gift for all the people, but participation in it requires each individual's personal decision. The way that enables the man to enter God's kingdom is built on the foundation of faith in Jesus as the Son of God and an acceptance of His testimony directed to people (v. 18). One should emphasise here that the faith in God is not based on feelings, but mainly on man's reason and the decision of will. Without the reason and the decision of will, it would be non resistant to any contradictions and difficulties which could break it ${ }^{17}$. However, it depends largely on the man if he wants to believe that he is the gift of God in the evangelical sense in the first order (v. 18). Christianity defines that the faith is given to the man by God without any credit. Nevertheless, this gift has to be cared by him, and he has to care for its development. The reflection of this care of faith is, among other things, an effort to know its contents and formation of the man's own life in accordance with its principles ${ }^{18}$.

Appointed by the speakers' (Jesus and Nikodemus) thinking course frees the question about the character of the human acts of doing, which will

16 Jan Kochel, Katecheza królestwa niebieskiego. Studium biblijno-katechetyczne Ewangelii Mateusza (Opole: Wydział Teologiczny Uniwersytetu Opolskiego, 2005), 14-16.

${ }^{17}$ Wojciech Cichosz, Pedagogia wiary we współczesnej szkole katolickiej (Warszawa: TYPO 2, 2010), 151

${ }^{18}$ Marek, Religia, 51. 
make the God's kingdom prophesied by Jesus real for the man. The teacher presents the witness in front of the pupil that the participation in the God's kingdom demands affirmation of His words and acts of doing. The values that are depicted to Nikodemus by Jesus allows us to outline the scope of the interests of the religious education. The first sight appears to be the discovery that it goes beyond the natural reality of the human life. Owing to a new form of cognition, which is the cognition drawing from the faith in Jesus, His words, His words and acts of doing, proposed by Jesus, the man has not only the opportunity to pose questions about the reality that exceeds the sensual-intellectual-empirical forms of cognition, but also to find the answers to them thanks to the beyond-natural source, which is in the Christianity - Revelation written down in the Holy Scripture and solidified in Tradition.

One should underline that providing that the knowledge is treated as the justified and some sort of cognition, which means the spiritual assimilation of all the issues that gives the certainty of existence on the basis of cognition emerging from own insight and experience - the faith expresses the affirmation of the explications of the human existence drawing from the God's revelation, also views considering another person's authority and witness. The feature of the faith means that it surpasses the reality, which is not accessible by reason. In this way, it becomes a very personal human act that is realised in two dimensions. That is why, to believe means, first of all, to accept the truth which is not definitely embraced by our mind, what God reveals about himself, the man, and the whole reality including this one which is unimaginative and inconceivable. In this sense, the revealed truth affirmed by man broadens the horizon of the human cognition. It also enables getting to the mystery, in which the human existence is dipped. To accept the limited possibilities of the cognition with the reason is not easy for the man. In such a situation the faith appears in the second dimension: as trust to the person - not the ordinary one, but Christ - the true God. This bears the implication that it is important what we believe in, but more crucial is whom we believe in ${ }^{19}$. The core of the faith is not only the acceptance of God's existence, but, first of all, getting personally in touch with Him and showing Him obedience. Thus, one can say that the religious cognition is on one hand, subjective, but on the other hand, is objective in the reference to the revealed truth.

The analysis of the biblical text enables us to assume that Jesus makes the man conscious of the limited possibilities of cognition. Thus God with his

19 John Paul II, Fides et ratio (Libreria Editrice Vaticana, 1998), n. 7-9. 
own authority comes to the man with help and ensures him of matters, which he is not capable of explaining through the empirical activity. It does not mean that the religious cognition gives the person the satisfactory answers to all her/his questions. Nevertheless, it gives the opportunity to broaden the knowledge of themselves and the world. In this light, one can assume that the religious cognition broadens the horizons of human cognition. This allows getting to the mystery in which his/her existence is dipped. Overcoming this border of limitation serves for the development of the man's inner spiritual sphere. We can then comment about the development of his spirituality ${ }^{20}$.

Assuming that the spirituality expresses the unity of the values sense, the sense that rules specific structures that can be individual, situational, corporative, national, or religious, one can claim that it refers both to the natural dimension and the experience of transcendence, as well. The spirituality is co-created by consciousness (cognition), emotionality (feelings), and values (including the religious ones) with the hierarchy that is affirmed. This is why it is attributed with the ability of building the lifestyle, cultural tendencies and the ways of practicing the cult. All of these qualities bear the conviction that the spirituality reflects in the CV based on the acceptance of the prior value, which is sacrum for the man. The result of it is the fact that the spirituality has a dynamic character, which enables the man to achieve new competences in the scope of understanding himself and the world, and conscious forming morality ${ }^{21}$. Such understanding of the spirituality justifies the correctness that can be seen in the process of the analysis of interactions of narration about the Christian origin, therefore the integration of values and expectations ${ }^{22}$.

In the analysed narration, the expectation of God's kingdom affirmation is inseparable with the values, that result with achieving the salvation through directing himself/herself to the light, loving the light, and doing good deeds (v. 19-21). Analogically, as in the case of values, these expectations can be matched to the actors of the first and second plan, leaving out in case of the second ones "whoever does not believe people have preferred darkness" (v. 18. 19). They are aligned with Nikodemus value of entering the God's kingdom with which Jesus connects the rebirth (v. 3). What should it be? Developing conscious relationships by man with God was very important for Jesus. Achieving this is conditioned by the belief that God neither wants to

${ }^{20}$ Zbigniew Marek, "Duchowość, religia i wychowanie", Pedagogika Społeczna 1 (2015): $11-13$.

${ }^{21}$ Marek, Pedagogika towarzyszenia, 97-98.

${ }^{22}$ Marek, Walulik, Pedagogika świadectwa, 181-231. 
take anything from the man, nor to harm him. In case of wrong understanding these expectations, what is proved by Nikodemus' questions: "How can anyone who is already old be born? Is it possible to go back into the womb again and be born?" (v. 4), Jesus, as a teacher, directs his thinking towards understanding the relationship with God saying:

In all truth I tell you, no one can enter the kingdom of God without being born through water and the Spirit; what is born of human nature is human; what is born of the Spirit is spirit. Do not be surprised when I say: You must be born from above. The wind blows where it pleases; you can hear its sound, but you cannot tell where it comes from or where it is going. So it is with everyone who is born of the Spirit (v. 5-8).

This answer is not understandable for Nikodemus and he needs from Jesus further explanations, which depict the necessity of using the religious cognition. Jesus does not have in mind the physical birth here, but "from water and Spirit" (v. 5), which means from God. Thus, he explains that this process occurs invisibly "The wind blows where it pleases; you can hear its sound, but you cannot tell where it comes from or where it is going. So it is with everyone who is born of the Spirit." (v. 8). Furthermore, this is aligned with the next expectation, which is directing to the light, loving the light, and making good deeds (v. 19-21). It means that God respects the man's freedom, but expects the faith and the making choice of Him from the man. Further, Jesus emphasises that it opens for the man the never-ending possibility of eternal life coming from the entrance to God's kingdom (v. 3.15). The man's faith in such God's intentions Jesus reinforces using the description of God's love to people (v. 16-18). Concurrently, Jesus makes Nikodemus conscious that the man will be judged for his acts of doing. He explains that such a judgement will consider the man's attitude to Him. Naming himself the Light, which has come to the world, by the way, he tells people sadly that they "have preferred darkness to the light because their deeds were evil" (v. 19).

These lasts explications that concern the expectations, requires the reference to other indicated values, which comprise love, truth, and good. The connection between them and the expectations understood above outlines in front of the religious education the concrete tasks aligned not only with the explications of the human existence, but also with providing the impulses to treat responsible the promise obtained from this. Its concrete reflection is seen in the human morality, which means the man's specific attributes that 
exteriorise his acts of doing. It is compared with the insight compass showing the man a reception of concrete ways of acting in particular life situation ${ }^{23}$.

Help in the interpretations of relations between the values and expectations is brought in by the other category mentioned in the analysis - time. In the story presented above, we indicated one main entity of this category expressed in the metaphor - night. Its interpretation demands the reference to understanding time as defined by Kairos ${ }^{24}$ and in the context of values and expectations it points at least two approaches: from natural and beyond natural perspective. The first one reveals that the man spontaneously associates the night with darkness in the shape of pain, chaos, or emptiness. He starts experiencing the belief that the whole humanity has been embraced by the "pitch-darkness". The beyond natural perspective is represented by the biblical understanding of darkness. The Bible in the darkness "sees" God, who infuses the night with his own light. The darkness cannot embrace God's lightness, as He rules over any darkness. Thus, the darkness in the Bible calls the presence of God and His lightness ${ }^{25}$. In the story presented above, the night is the time in which a new understanding of reality "occurs". This reality is known by the pupil on their natural cognition. He/she begins to understand that God's Spirit lives in the man. This Spirit gives him/her the light to know how to live. This discovery has the character of a subjective relationship with the subject of cognition, for it is God as a person.

\section{The pedagogical support for discovering own subjectivity - the pedagogical implications}

The interpretation of the biblical pericope, already depicted, leads to some implications which describe the Christian understanding of subjectivity in the processes of upbringing. The foundation of its understanding is the assumption that every man is a person, who features with dignity, and is able to share their own experience not only through providing the answers, but also indicating their own areas of the lack of knowledge and own needs. In the narration, there were not only the questions posed by Nikodemus, who-

23 Zbigniew Marek, Podstawy wychowania moralnego (Kraków: WSFP Ignatianum, WAM, 2005), 32.

${ }^{24}$ Marek, Walulik, Pedagogika świadectwa, 30-31.

${ }^{25}$ Krzysztof Wons, Gdy Bóg przychodzi w ciemnościach (Kraków: Salwator, 2015), 17. 
as we could notice during the interpretation - is the representative of every man - takes in the answers given by Jesus, but, first of all, who discovers God contributes in the history of humanity. The dialogue between the teacher and student brings the conscience that "The desire for God is written in the human heart, because man is created by God and for God; and God never ceases to draw man to himself. Only in God will he find the truth and happi-

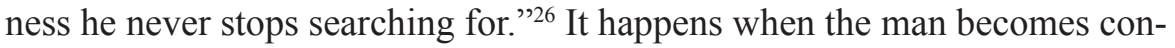
scious of the fact that he is "created in God's image and called to know and love him" "27. It means that the resemblance to God means that the sense and existence of human are constitutive in the deepest way connected with God. This relationship with God can be ignored, forgotten, or rejected, but it can never be deleted definitely ${ }^{28}$. Its basis is the human act named faith, which is featured not only with acceptance of the existence of Transcendence - God, but, first of all, the reference of their own life to Him, his own existence. With it, the human expresses not only their own dependence on God, but also shows Him their own trust. This mindset cannot exclude the use of own reason by the person. This is why one should say that the faith and reason are like two wings, on which the human spirit soars towards the contemplation of the truth ${ }^{29}$.

The interpretation shown in the pericope of the biblical categories and relationship between them makes conscious that the man, in recognising himself and the world, can use the natural and religious cognition and thanks to it he can discover the intentions of God, his Creator and Saviour on the way of the interactions. Meaningful in understanding presented categories in the narration is also the fact that the man created by God, in the Bible understanding, is the summit, crowning the masterpiece of the creation. Based on this truth, the true Christianity explicates also the sense of possessed dignity to be the person:

Being in the image of God the human individual possesses the dignity of a person, who is not just something, but someone. He is capable of self-knowledge, of self-possession and of freely giving himself and entering into communion with other persons. And he is called by grace to a covenant with his Creator,

${ }^{26}$ Catechism of the Catholic Church, n. 27.

27 Ibidem, n. 31.

${ }_{28}$ Papieska Rada Iustitia et Pax, Kompendium nauki społecznej Kościoła (Kielce: JEDNOŚĆ, 2005), n. 109.

29 John Paul II, Fides, n. 8. 
to offer him a response of faith and love that no other creature can give in his $\operatorname{stead}^{30}$.

Bartosz Brożek notices that the term "person" in the Church social science has the initial and axiological (normative) charter: is not reduced to the simpler notions and regards the person as the subject of moral rights and duties ${ }^{31}$. One should remember that this term has had different meanings throughout the history of the world; it has been encumbered with a long history and involved in varied philosophical systems often competing with themselves. Furthermore, the term "Person" can be the tool of notion, which helps to express some contents that are often very crucial. However, this tool is only the tool, and it cannot obscure the goal for which it is applied ${ }^{32}$. The most frequently evoked definition is one by Boethius, who defined the person as the peculiar substance of reasonable nature ${ }^{33}$.

To see the value of the person leads us to pay attention to the fact that there are two contemporary promoted concepts by the descriptive and axiological theory. In the first one, the accent is put on an identification of empirical criteria enabling it to differentiate the persons from non-persons. In the second one, the person is the value, the subject of rights and duties ${ }^{34}$. The axiological explication of the term "person" is connected with the conscious, free, and responsible acting, which is founded on the ability of the world cognition. This term also enables the man to discover the fact that he is not alone in the world, but lives in it altogether with other persons ${ }^{35}$. Differentiating "otherness" and "distinctiveness" of particular persons is called colloquially dignity. It belongs to the human nature. In the context of these explanations, it is necessary to add that independently of the accepted concept of understanding the notion "person", this term always expresses "unspeakable mystery" 36 , in which the man's significant dignity is expounded. It emerges from the human natural capacity of cognition, love, acting in freedom, and becoming the subject of rights and duties. This makes him able to overcoming the borders of the non-material world. This ability enables him to get to

\footnotetext{
${ }^{30}$ Catechism, n. 357.

31 Brożek, "O pojęciu osoby”, 175.

32 Ibidem, 165.

${ }^{33}$ Marek, Pedagogika towarzyszenia, 136.

34 Brożek, "O pojęciu osoby”, 166-167.

${ }_{35}$ Marek, Pedagogika towarzyszenia, 136.

${ }^{36}$ Brożek, "O pojęciu osoby”, 164.
} 
know his own humanity recognised in the light of relations connecting the person with nature, culture, and transcendence ${ }^{37}$, and sometimes is called the transcendenta ${ }^{38}$. The key to understanding the Christian explanation of human dignity is Jesus Christ: His incorporation and salvation of the man on the cross and His resurrection. Thus, we state that the man was not only created by God, but also freed from the power of bad, sin, and death by Jesus Christ, and also invited to participate in His life (immortality) ${ }^{39}$. Feeling down into one's own subjectivity can lead to openness to another man and enables creating the interpersonal relationships on the path of dialogue. It demands the reflective, open, divergent, and critical approach to the researched reality and implies the person's development and self-development; the result means the transformative character of the researched reality ${ }^{40}$.

In the conducted analysis, we have paid attention to understanding the subjectivity in upbringing. As far as this is concerned, we mean discovering the ability of posing the questions and seeking the answers to them, which can also be given to the man by God. Readiness to accept such perceived subjectivity seems to be the fruit of the religious education. They show that the sense of the religious education is to support the man in developing his humanity and achieving its completeness, which Christianity combines with the life fulfilled with happiness and love. It is defined as God's kingdom, which features with immortality and eternity.

The interpretations of the connections between the subjectivity of upbringing and the religious education pay attention to the transcendental dimension of the human life, in which God as the person performs a crucial role. Such seen upbringing validates the thesis that includes the Christian upbringing into the triad of the following subjects cooperating with each other: God, who being an appropriate subject initiates and realizes his intentions serving the man's complete development and good, and other subjects created - the form teacher, and the pupil. In the activity of these last ones, respecting the assumptions of the pedagogy of accompaniment and witness can appear to be crucial. These assumptions do not only exclude the different

${ }^{37}$ Marian Nowak, "Pedagogika personalistyczna", in: Pedagogika, eds. Zbigniew Kwieciński, Bogusław Śliwerski (Warszawa: PWN, 2005), 242.

${ }^{38}$ Mieczysław Albert Krąpiec, "Człowiek - interpretacja filozoficzna”, in: Encyklopedia katolicka, vol. III, ed. Romuald Łukaszczyk, Ludomir Bieńkowski, Feliks Gryglewicz (Lublin: TN KUL, 1979), 914-917.

${ }^{39}$ Marek, Podstawy, 23.

${ }^{40}$ Marek, Walulik, Pedagogika świadectwa, 25. 
tasks of each of these subjects, but also make them sensitive to the joint elements, on which the activity of each these subjects is based. The form teacher's tasks are expressed in the discrete closeness to the pupil. This closeness is shown in providing him with the indispensible knowledge necessary for interpreting the gathered experiences in the natural and religious perspective. The form teacher also inspires the pupil to undertake the concrete acts of doing, growing from understanding the meaning of values that become known. Finally, he/she helps the pupil evaluate activities undertaken by him. This means that the religious education characterises with the humanistic and religious education.

\section{References}

Archer, Margaret Scotford, Andrew Collier, Douglas V. Porpora. Transcendence. Critical Realism and God. London and New York: Routledge, 2004.

Brożek, Bartosz. "O pojęciu osoby". In: Polonia restituta. Dekalog dla Polski w 100-lecie odzyskania niepodległości, eds. Wit Pasierbek, Anna Teresa Budzanowska, 359-378. Kraków: MNiSW, Akademia Ignatianum, 2019.

Cichosz, Wojciech. Pedagogia wiary we wspótczesnej szkole katolickiej. Warszawa: TYPO 2, 2010.

Dziaczkowska, Lucyna. "Podmiotowość". In: Encyklopedia aksjologii pedagogicznej, eds. Krystyna Chałas, Adam Maj, 781-785. Radom: POLWEN, 2016.

John Paul II. Fides et ratio. Libreria Editrice Vaticana, 1998.

Catechism of the Catholic Church. Bloomsbury Publishing PLC, 2002.

Kochel, Jan. Katecheza królestwa niebieskiego. Studium biblijno-katechetyczne Ewangelii Mateusza. Opole: Wydział Teologiczny Uniwersytetu Opolskiego, 2005.

Krąpiec, Mieczysław Albert. "Człowiek - interpretacja filozoficzna”. In: Encyklopedia katolicka, vol. III, eds. Romuald Łukaszczyk, Ludomir Bieńkowski, Feliks Gryglewicz, 814-817. Lublin: TN KUL, 1979.

Krysztofik, Janusz, Anna Walulik. "Edukacja religijna i jej miejsce w ponowoczesności”. Studia Katechetyczne. Wspótczesne ujęcia edukacji religijnej 12 (2016): $35-50$.

Marek, Zbigniew. "Duchowość, religia i wychowanie". Pedagogika Społeczna 1 (2015): 9-22.

Marek, Zbigniew. Pedagogika towarzyszenia. Perspektywa tradycji ignacjańskiej. Kraków: Akademia Ignatianum, 2017. 
Marek, Zbigniew. Podstawy wychowania moralnego. Kraków: WSFP Ignatianum, WAM, 2005.

Marek, Zbigniew. Religia pomoc czy zagrożenie dla edukacji. Kraków: WAM, 2014.

Marek, Zbigniew, Anna Walulik. Pedagogika świadectwa. Perspektywa antropologiczno-kerygmatyczna. Kraków: Akademia Ignatianum, 2019.

Nowak, Marian. "Pedagogika personalistyczna". In: Pedagogika, eds. Zbigniew Kwieciński, Bogusław Śliwerski, 232-247. Warszawa: PWN, 2005.

Papieska Rada Iustitia et Pax. Kompendium nauki społecznej Kościoła. Kielce: Jedność, 2005.

Stola, Krzysztof. "Podmiot”. In: Encyklopedia katolicka, vol. XV, ed. Edward Gigilewicz, 946-947. Lublin: TN KUL Jana Pawła II, 2011.

Waga, Leszek. "Integration of Pedagogical Knowledge in the Light of Questions about the Empirical Foundations of General Pedagogy and Understanding of the Concept of Generality". Peadagogia Christiana 2/42 (2018): 65-83.

Walulik, Anna. Moderacyjne i synergiczne ksztaltowanie dorostości. Propozycja typologii znaczeń wiedzy religijnej. Kraków: WSFP Ignatianum, WAM, 2011.

Wons, Krzysztof. Gdy Bóg przychodzi w ciemnościach. Kraków: Salwator, 2015. 